\title{
Review
}

\section{Anarchism and art: Democracy in the cracks and on the margins}

\author{
Mark Mattern \\ State University of New York Press, $x+187$ pp., ISBN: 978-1-4384-5920-2
}

Contemporary Political Theory (2018) 17, S209-S211. https://doi.org/10.1057/s41296017-0168-1; published online 6 December 2017

Anarchism and Art takes its cue from British theorist Colin Ward's observation that anarchist modes of social organizing can multiply and exist side-by-side with and 'in spite of' antithetical authoritarian societal 'trends' (p. 5). These practices are regarded as prefigurative: they model aspects of the future society anarchists seek to establish (p. 2). As such, anarchists regard them as powerful tools for revolutionizing the entire political, social, and economic order in times of upheaval (Gordon, 2007, p. 38). We have an unfolding example of what this entails in northern Syria, where anarchists have seized territory in three decentralized 'cantons' and are remodeling society based, in part, on anti-sexist organizing pioneered by fighters in the People's Defence Forces and Women's Defence Units (Strangers in a Tangled Wilderness, 2015, pp. 33-35). However, perusing Anarchism and Art for a discussion of prefiguration's role in anti-state social transformation is a futile exercise. 'Revolution' does not even make it to the index. Instead, Mattern subsumes anarchist modes of prefiguation within a 'participatory democracy' model of social change that 'does not advocate the complete abolition of the state' (p. 29). Over a page and a half, he sketches out his hypothetical program for reconstructing society along 'participatory democracy' lines, effectively purging anarchism's anti-statist history and principles from his framework (pp. 21-22). This echoes the argumentative style of philosopher Simon Critchley, who, with a cursory nod toward contemporary anarchist-inspired activism, has coined his own hypothetical formulation, 'neo-anarchism,' to encapsulate a 'politics at a distance from the state' perpetually incapable of superseding what it opposes, a formulation Critchley champions in his much-praised statement, Infinitively Demanding, as the only option for 'new social mobilizations' (Critchley, 2008, p. 148).

What we have, then, is a study that must, perforce, decouple its field of inquiry from post-statist ends to make its case. Accordingly, Mattern gently nudges the movement's revolutionary ambitions regarding 'state and capital' to the sidelines, suggesting that 'in the last several decades' anarchists have 'broadened' their

(c) 2017 Macmillan Publishers Ltd., part of Springer Nature. 1470-8914 Contemporary Political Theory Vol. 17, S4, S209-S211 www.palgrave.com/journals 
'focus' to encompass other pressing matters, notably animal rights, the environmental crisis, patriarchy, white supremacy, speciesism, and heterosexism (p. 30). In fact, anarchists have long engaged with such issues, and the implication that they are now treated as spheres of domination apart from 'state and capital' is disingenuous (Gelderloos, 2010); but on the plus side, putting 'state and capital' in its place helps grease the elision of 'anarchism' with 'participatory democracy.' In short, Mattern's book should be entitled Participatory Democracy and Art. However, in the absence of a 'participatory democracy' social movement or any evidence that the theory he promotes has impacted the arts under discussion, we have only a 'sleight of hand' exercise.

The analysis of the 'popular' art practices he consigns to the 'cracks and margins' of society - Chapter 3 'DIY (Do It Yourself) Punk Music'; Chapter 4 'Poetry Slam'; Chapter 5 'Graffiti and Street Art'; and Chapter 6 'Flash Mobs' - is sieved, formulaically, through four questions:

What form (s) of social organization and political action does this popular art form model? How does it challenge domination while increasing capacity? What does it say about equality and freedom? And, in each case, how does it prefigure a more democratic future? (pp. 37-38)

To this end, each chapter is divided into subsections (social organization; political action; power; equality; and freedom), presumably for ease of comparison. But a disquieting sense of déjà $v u$ animates the discussion. For example, in Chapter 3 'DIY (Do It Yourself) Punk Music,' under the subheading, 'social organization,' we learn 'the highly decentralized and extensively networked world of DIY punk music closely resembles the rhizomatic model of social organization characteristic of contemporary anarchism' (p. 41). Turning to 'social organization' in Chapter 4 'Poetry Slam,' we are told, 'slam poetry resembles the rhizomatic model familiar to anarchists' (p. 64). Flipping forward to the 'freedom' subheading in Chapter 5 'Graffiti and Street Art,' we discover 'the kind of freedom embraced by anarchists requires a capacity for critical consciousness and autonomous choice' (p. 98). Ditto for 'freedom' in Chapter 6 'Flash Mobs,' which announces, 'critical consciousness is essential for anarchist and participatory democratic understandings of freedom and autonomy' (p. 121). Hitting reverse, the 'power' subheading in Chapter 6: 'Flash Mobs,' proclaims 'flash mobs challenge the established, conventional order that is structured and controlled by state and corporate power' (p. 113) while, in Chapter 5 'Graffiti and Street Art,' under 'power,' graffiti and street art 'represent direct, explicit attacks on capital and the state and their control over urban public space' (p. 91). These are broad-brush generalizations that belie reality, as Mattern frequently concedes. For example, graffiti and street art are not immune to commodification (pp. 100-102); businesses mobilize flash mobs to market products (p. 118); slam poets have courted corporate sponsorship (p. 75); and the punk rock scene has serious gender-inequality issues to work through (p. 55). These and other 
fissures cast doubt on Anarchism and Art's equation of modes of art production with a singular political tradition, even if there are powerful anarchizing currents, the British punk rock group Crass being a case in point (pp. 44-46).

Mattern does make a convincing case for the value of prefigurative activism and the ways in which anarchist theory and practice pivots on radicalizing everyday life. His opening chapter on 'Anarchism and Democracy' also mounts a convincing critique of liberal democratic institutions and their connivance with capitalism while outlining, by way of contrast, how anarchism's grassroots activism expands the range of democratic expression (pp. 17-38). That said, social revolution is central to anarchism's radicalization of culture, including the arts: Mattern's study flounders because he refuses to probe the implications.

\section{References}

Critchley, S. (2008) Infinitely Demanding: Ethics of Commitment, Politics of Resistance (p. 2008). London: Verso Press.

Gelderloos, P. (2010) Anarchy Works: Examples of Anarchist Ideas in Practice. Oakland, CA: Ardent Press.

Gordon, U. (2007) Anarchy Alive!: Anti-Authoritarian Politics from Practice to Theory. London: Pluto Press.

Strangers in a Tangled Wilderness (ed.). (2015) A Small Key can Open a Large Door: The Rojava Revolution. San Bernardino, CA: Combustion Books.

Allan Antliff

University of Victoria, Victoria, BC V8P 5C2, Canada

allan@uvic.ca 